\title{
Kepercayaan dan Hegemoni dalam Cerpen "Dukun yang Selamat" Karya Joni Hendri (Kajian Hegemoni Gramsci)
}

\author{
Fajrul Falah \\ Fakultas Ilmu Budaya, Universitas Diponegoro \\ fajrul.falah@live.undip.ac.id
}

\begin{abstract}
The purpose of this study expresses trust and hegemony in a short story "Dukun yang Selamat" by Joni Hendri. Short Story "Dukun yang Selamat" interesting research because it contains differences in belief in the existence of shamans. The research approach used is Gramsci's hegemony, entering the realm of sociology of literature. This research belongs to the field of library research, not field research. This study used descriptive qualitative method. Research data obtained from words, phrases, sentences, and dialogues contained in short story "Dukun yang Selamat" which is relevant to belief and hegemony. The research data was analyzed by interpreting it according to the research approach used. The results showed differences in attitudes and behaviors towards figures Nenek Sari or a shaman is caused by the trust of each individual. The beliefs that have been adhered to and believed to be true are able to make a character Wak Atan acting that is not justified, which is to kill the shaman. The hegemony of belief is able to make Wak Atan marginalize the role of humans who are considered shamans.
\end{abstract}

Keywords: Belief; hegemony; shaman; behavior; and role.

\section{Intisari}

Tujuan penelitian ini mengungkapkan kepercayaan dan hegemoni dalam cerita pendek "Dukun yang Selamat" karya Joni Hendri. Cerpen "Dukun yang Selamat" menarik diteliti karena memuat perbedaan kepercayaan terhadap keberadaan dukun. Pendekatan penelitan yang dipakai adalah hegemoni Gramsci, masuk ranah sosiologi sastra. Penelitian ini masuk ranah penelitian kepustakaan, bukan penelitian lapangan. Penelitian ini menggunakan metode deskriptif kualitatif. Data penelitian didapatkan dari kata, frasa, kalimat, dan dialog yang terdapat dalam cerpen "Dukun yang Selamat" yang relevan dengan kepercayaan dan hegemoni. Data penelitian itu dianalisis dengan cara diinterpretasikan sesuai dengan pendekatan penelitian yang dipakai. Hasil penelitian menunjukkan perbedaan sikap dan perilaku terhadap tokoh Nenek Sari atau dukun disebabkan oleh kepercayaan tiap-tiap individu. Kepercayaan yang telah dianut dan diyakini kebenarannya mampu membuat tokoh Wak Atan bertindak yang tidak dibenarkan, yakni ingin membunuh dukun itu. Hegemoni kepercayaan mampu membuat Wak Atan memarjinalkan peran manusia yang dianggap sebagai dukun.

Kata kunci: Kepercayaan; hegemoni; dukun; perilaku; dan peran. 


\section{Pendahuluan}

Tiap-tiap individu dalam kehidupan bermasyarakat, umumnya memiliki kepercayaan masing-masing. Kepercayaan yang dianut individu itu, bisa bersumber dari pengetahuan atau pengalaman. Jika kepercayaan itu bersumber dari kebiasaan atau pengalaman, maka nilai kebenaran (ilmiah) pun dianggap parsial atau lemah. Kepercayaan itu bahkan cenderung dianggap mitos. Kepercayaan itu dianggap benar oleh mereka yang mempercayainya. Kepercayaan jika penganutnya cenderung banyak (dominan) dalam masyarakat, maka akan memberikan kekuatan. Konflik antarpribadi yang ditimbulkan atas kepercayaan itu pun relatif minim atau sedikit. Jika penganut atau pengikut kepercayaan itu sedikit (minor) dalam masyarakat, maka bisa menjadi masyarakat yang dimarjinalkan oleh kelompok dominan. Konflik antarkepercayaan pun muncul. Kelompok minor dalam masyarakat cenderung bertahan (defense), tidak menonjolkan konfrontasi langsung dengan kelompok dominan.

Persoalan yang terkait dengan kepercayaan dan mitos yang terdapat dalam kehidupan manusia, bisa ditemukan dalam cerita fiksi, yakni cerita pendek "Dukun yang Selamat" karya Joni Hendri. Cerita pendek (cerpen) yang secara space dan karakter lebih pendek dan padat dibandingkan novel, sarat makna seperti merefleksikan dunia realitas. Disebut refleksi (baca: bukan cermin) karena dalam cerpen sekalipun mengambil isu/tema/konflik yang terjadi dalam kehidupan riil, ada peran pengarang yang signifikan. Pengarang memiliki otoritas penuh dalam menentukan tokoh fiksi atau imajiner dan jalan cerita yang memiliki kemiripan bahkan penyimpangan dari realitas sesungguhnya. Pada konteks ini, karya yang dihasilkan tidak lepas dari latar belakang pengarangnya. Latar belakang pengarang itu umumnya dipegaruhi oleh pendidikan, lingkungan, peran dan profesi.

Cerpen "Dukun yang Selamat" selanjutnya disingkat "DyS" karya Joni Hendri ini dimuat di Harian Tanjungpinang Pos 8 Maret 2020. Cerpen "DyS" ini seperti merefleksikan sebagian kehidupan masyarakat di Indonesia yang sebagian mempercayai efek (kekuatan) dukun. Cerpen yang dimuat kembali di lakonhidup.com ini menarik diteliti selain memuat tema atau isu tentang kepercayaan terhadap dukun, juga tokoh-tokoh dalam cerpen mewakili dan menganut kepercayaan yang berbeda. Persoalan utama dalam cerpen itu pun bisa dibaca atau dimaknai pembaca. Tokoh-tokoh yang dimunculkan dalam cerpen itu pun relatif terbatas, yakni Wak Atan, Pak Itam, Nenek Sari (dukun), remaja, dan orang 
kampung. Mengapa sebagian tokoh sepeti Wak Atan tidak menerima keberadaan nenek Sari di kampungnya. Apakah nenek Sari melawan atau sebagai ancaman Wak Atan? Mengapa pula Pak Itam berbeda pandangan dengan Wak Atan terkait keberadaan dukun di kampungnya. Bagaimana pula kehidupan peran yang dimainkan oleh Nenek Sari?

Penelitian terhadap cerpen “"DyS” ini bertujuan untuk mengungkapkan kepercayaan dan hegemoni. Sebelum masuk ke analisis kepercayaan dan hegemoni, dideskripsikan sinopsis cerpen. Selain argumentasi dan tujuan penelitian tersebut, cerpen "DyS" ini menarik diteliti juga karena belum ditemukan penelitian serupa. Sepanjang pengetahuan penulis, didasarkan penelusuran di google dan jurnal online yang terindeks doaj.org, dengan memasukan kata kunci cerpen "Dukun yang Selamat", tidak ditemukan hasil penelitian.

Ada penelitian yang terkait dengan kepercayaan dan hegemoni, di antaranya (1) Falah (2019) memakai kajian hegemoni pada objek material cerpen "Makelar" karya Sri Lim R.N. Fokus penelitian itu mengungkapkan karakter dan kepercayaan tokoh dalam cerpen. Hasil penelitian menunjukkan hegemoni kepercayaan dilakukan untuk mendapatkan keuntungan (profit). Tokoh Handoko sebagai makelar mendapatkan keuntungan dari pihak-pihak yang memakai jasa makelarnya. Penelitian lain, Falah (2019) menggunakan kajian hegemoni dan ideologi dengan memakai objek material cerpen “Surga untuk Lelaki yang tertipu”. Penelitian ini difokuskan mebgungkap bentuk ideologiideologi yang berkembang dalam cerpen. Ideologi itu kemudian dijadikan alat untuk menghegemoni antartokoh. Hasil penelitian terhadap cerpen itu menunjukkan ideologi yang didistribusikan oleh sang guru kepada murid (Santo) satu pihak dianggap berhasil. Santo mengikuti ajaran dan apa kata gurunya. Dua penelitian tersebut memakai objek material berbeda. Peneliti akan mengungkapkan kepercayaan dan hegemoni dalam cerpen "DyS" karya Joni Hendri dengan perspektif hegemoni Gramsci. Penelitian ini masuk ranah sosiologi sastra.

Kepercayaan merupakan keyakinan yang dimiliki individu dalam sebuah masyarakat. Keprcayaan bisa didapatkan melalui pengetahuan dan pengalaman baik pribadi maupun orang lain. Kepercayaan bisa dijadikan modal sosial. Kepercayaan yang dianut oleh kelompok dominan mampu menumbuhkan kekuatan dan meninimalisasi konflik antarindividu. Kepercayaan dalam hal ini bisa menjadi modal sosial bagi individu. Kepercayaan individu terhadap individu yang memiliki kekuatan magis, bisa mendapatkan 
berbagai reaksi dalam masyarakat (Lihat Falah, 2019; Setyawati et al., 2010). Hegemoni merupakan kekuasaan tidak sekadar dalam dunia pemerintahan atau negara. Negara yang kuat menguasai negara yang lemah. Hegemoni juga bisa diartika kekuasaan yang didapat oleh atau berdasarkan kelas sosial tertentu. Tiap-tiap individu dalam masyarakat umumnya memiliki strata atau kelas sosial. Kelas sosial itu diterima dengan sukarela. Hegemoni didapat pun dengan cara persuasi, bukan paksaan (Lihat Kurniawan, 2012: 71-73; Fajrul, 2018: 353). Hegemoni dalam konteks penelitian ini, dimaknai sebagai bentuk kekuasaan dan perilaku tokoh yang didasarkan pada kekuatan pengetahuan dan kepercayaan.

\section{Metode Penelitian}

Penelitian ini memakai objek material cerpen berjudul "Dukun yang Selamat" karya Joni Hendri yang dimuat di Harian Tanjungpinang Pos, 8 Maret 2020. Penelitian ini memakai objek formal hegemoni kepercayaan yang terdapat dalam cerpen itu. Pendekatan penelitian yang digunakan dalam penelitian ini adalah hegemoni Gramsci, masuk ranah sosiologi sastra. Penelitian ini masuk ranak penelitian kepustakaan (library research), bukan penelitian lapangan (field research). Data utama (primer) dalam penelitian ini diambilkan dari data tertulis, yakni cerpen "Dukun yang Selamat" yang diakses di laman lakonhidup.com. Langkah kerja atau operasionalisasi dalam penelitian kepustakaan ini meliputi (1) pengumpulan data, (2) analisis data, dan (3) penyajian hasil. Pengumpulan data memuat pemilihan objek material, yakni cerpen "Dukun yang Selamat". Cerpen itu kemudian dibaca secara cermat dengan memilah dan memberikan tanda pada kata, frasa, dan kalimat yang terkait dengan hegemoni dan kepercayaan. Data penelitian dari cerpen tersebut, kemudian dianalisis dengan cara diinterpretasikan atau ditafsirkan berdasarkan atau terkait pendekatan dan objek formal penelitian, yakni hegemoni dan kepercayaan. Hasil analisis itu, kemudian disajikan secara deskriptif kualitatif.

\section{Hasil dan Pembahasan}

Bab hasil dan pembahasan ini memuat tiga subbab, yakni sinopsis cerpen, kepercayaan tokoh utama terhadap dukun, dan hegemoni kepercayaan dalam Cerpen "Dukun yang Selamat" Karya Joni Hendri. Sinopsis disajikan untuk memberikan gambaran terkait cerpen "DyS" ini dan memudahkan analisis. 


\section{Sinopsis Cerpen "Dukun yang Selamat"}

Cerpen "Dukun yang Selamat" Karya Joni Hendri yang dimuat di Tanjungpinang Pos pada 8 Maret 2020 ini memuat cerita tentang dukun. Cerpen yang memfokuskan cerita posisi dukun ini, meskipun secara space (kata, halaman, konflik) terbatas, namun pesan utama dalam cerpen tersebut bisa didapat pembaca. Pengarang mampu menampilkan dan mengemas cerita terkait dukun (aktifitas) mirip sebagian dunia realitas sesungguhnya. Pilihan kata (diksi) yang terdapat dalam cerpen ini didominasi kata-kata yang relevan dengan aktifitas dan atribut dukun. Diksi yang melekat pada dukun itu dalam cerpen "DyS" ini, yakni kepercayaan, mantra, komat-kamit, nenek, kampung, mengobati, bala, dan mitos. Kata atau tokoh dukun dalam cerpen ini menjadi sentral atau fokus cerita. Latar fiksi yang digunakan dalam cerpen itu yakni sebuah kampung, mirip sebagaimana sebagian dukun hidup dalam realitas sesungguhnya.

Tokoh-tokoh dalam cerpen "DyS” ini relatif terbatas, yakni tokoh Nenek Sari (diduga dukun), Pak Itam (tetangga Sari), dan Wak Atan (orang kampung/pemilik ladang), dan remaja kampung. Tiap-tiap tokoh memiliki dan menjalankan perang masing-masing. Tokoh Nenek Sari diduga sebagai dukun oleh orang kampung atau tokoh Wak Atan. Dugaan itu didasarkan pada atribut yang melekat pada Nenek Sari (perempuan tua dan menyendiri) dan kepercayaan orang kampung (Wak Atan) terhadap dukun. Orang kampung atau Wak Atan dalam cerpen itu menyakini bahwa jika panen gagal (paceklik), disebabkan ada keberadaan dukun dalam kampung tersebut. Tokoh berbeda, Pak Itam selain sebagai tetangga Nenek Sari, ia memerankan sebagai tokoh penengah dan menyelamatkan tokoh yang diduga dukun (Sari). Adapun tokoh remaja (berpendidikan) hanya disinggung sekilas karena bukan merupakan tokoh utama atau yang memiliki peran penting dalam cerpen itu.

Tiap-tiap tokoh dalam cerpen "DyS" ini memiliki kepercayaan dan pandangan berbeda terhadap dukun. Tokoh Wak Atan merepresentasikan sebagian orang kampung yang percaya terhadap mitos, takhayul, dan keberadaan dukun. Mitos dan kepercayaan Wak Atan dan sebagian orang kampung diantaranya keberadaan dukun bisa mengakibatkan paceklik (gagal panen) dan mendatangkan bala (musibah). Kepercayaan Wak Atan itu kemudian berkembang menjadi menimbulkan tindakan (agresif) terhadap keberadaan dukun. Wak Atan ingin mencari bahkan membunuh dukun yang berada di kampungya. Berbeda dengan Wak Atan, Pak Ita, sekalipun percaya bahwa tokoh Nenek 
Sari adalah dukun, namun ia tidak mempercayai bahwa musibah yang menimba disebabkan keberadaan dukun. Pak Itam bahkan menjadi tokoh penyelamat bagi Nenek Sari. Akhir cerita dalam cerpen “DyS” ini sesuai dengan judul cerpen, yakni dukun yang selamat, dari ancaman orang kampung (happy ending).

\section{Kepercayaan dalam Cerpen "DyS"}

Ada dua tokoh utama atau kubu yang secara jelas berbeda kepercayaan terhadap keberadaan dukun (tokoh Nenek Sari) dalam cerpen "DyS", yakni tokoh Wak Atan dan Pak Itan. Perbedaan kepercayaan itu memicu dan menimbulkan konflik antartokoh dalam cerpen.

\section{Kepercayaan Tokoh Wak Atan}

Tokoh sentral Wak Atan, merepresentasikan sebagai pihak yang mempercayai bahwa keberadaan dukun (Nenek Sari) di kampungnya sebagai sumber malapetaka. Kepercayaan Wak Atan muncul dari akumulasi pengetahuan yang didapatkan dari pengalamanpengalaman sebelumnya. Berdasarkan pengamatan dan pengalaman Wak Atan, jika sawah yang ditanami padi tidak berbuah dan terdapat banyak burung pipit yang membawa awan gelap, maka dipercaya terdapat dukun yang berada di kampung halamannya. Tanda-tanda itu diyakini benar oleh Wak Atan, "Ini peristiwa yang sudah lama tidak kembali ke kampung ini"ujar Wak Atan dalam hati (DyS, 2020: 3). Kecurigaan dan kepercayaan Wak Atan terhadap tanda-tanda dan peristiwa itu didasarkan pada pengalaman sebelumnya, yakni peristiwa (malapetaka/bala) berhenti manakala dukun ketujuh di kampungnya telah dibunuh.

Kepercayaan Wak Atan terhadap bahaya yang ditimbulkan karena keberadaan dukun, menunjukkan ia lebih mempercayai mitos dan takhayul daripada logika ilmiah. Kepercayaan terhadap dunia takhayul dan mitos itu, tidak hanya Wak Atan, melainkan juga sebagian warga yang tinggal di kampungnya, "Di kampung itu orang-orang mempercayai benda-benda takhayul, atau hal-hal mitos" (DyS, 2020: 3). Kutipan tersebut menunjukkan bahwa fenomena atau kejadian alam (gagal panen) dipercaya oleh orang kampung itu, disebabkan kekuatan-kekuatan yang tidak nampak dan tidak bisa dibuktikan kebenarannya secara empirik (ilmiah).

Wak Atan dan sebagian orang kampung yang percaya mitos itu, tidak mengedepankan logika berpikir secara ilmiah terkait penyebab ladang padi yang tidak 
berbuah atau panen. Wak Atan tidak mencari tahu dan membuktikan penyebab panen gagal secara logis; apakah tanaman dirusak hama atau pupuk tanam yang tidak memadai.

Jika Wak Atan berpikir secara rasio atau ilmiah, maka dugaan (hipotesis) yang muncul mengapa padi tidak berbuah dan terjadi paceklik adalah (1) keberadaan burung pipit di ladang tidak dimaknai sebagai binatang yang membawa awan gelap atau malapetaka, tetapi sebagai hama bagi tanaman padi. Brung pipit (emprit) sebagai hama, menyerang ladang dan memakan sekaligus merusak padi. Burung pipit, bagi petani, menjadi ancaman nyata dan membuat padi gagal panen. Sebagai ancaman yang kasat mata, burung pipit bisa diperangi atau basmi oleh petani dengan startegi dan cara masing-masing. Cara umum yang dilakukan petani untuk mengusir hama tersebut diantaranya membuat jaring, membuat perangkap/membuat orang-orangan sawah, dan memberikan benda dan tanaman mencolok di sekitar. Keberadaan burung pipit di sawah tidak sekadar dibiarkan, lalu dikambinghitamkan sebagai binatang kelas aves yang dipercayai membawa malapetaka.

\section{Kepercayaan Tokoh Pak Itam}

Tokoh Pak Itam dalam cerpen "DyS" memiliki persamaan dan perbedaan kepercayaan dengan tokoh Wak Atan. Kedua tokoh itu mempercayai bahwa di kampung halamannya terdapat dukun. Dukun yang dimaksud dua tokoh itu adalah Nenek Sari. Hal itu ditujukan Pak Itam saat mendengar Nenek Sari sedang membaca mantra untuk mengobati cucunya, "Selama ini memang tidak pernah terdengar. Bahwa dia seorang dukun. Ini aneh! Bisik hati Pak Itam dengan keheranan” (“DyS”, 2020:2). Kutipan tersebut menunjukkan bahwa Pak Itam percaya bahwa Nenek Sari yang diduga dukun oleh Wak Atan dan orang kampung, diindikasikan benar. Meskipun demikian, sikap dan perilaku Pak Itam terhadap keberadaan dukun berbeda dengan Wak Atan dan sebagian orang kampung.

Pak Itam memiliki karakter dan peran secara umum cenderung kontras dibandingkan Wak Atan. Jika tokoh Wak Atan memusuhi bahkan ingin membunuh dukun, maka Pak Itam justru menjaga dan meyelamatkannya. Pak Itam tidak mempercayai mitos dan takhayul, bahwa keberadaan dukun mengakibatkan gagal panen, sebagaimana kepercayaan Wak Atan dan sebagian orang kampung dalam cerpen itu. Pak Itam menganggap Nenek Sari seperti manusia biasa yang butuh pertolongan dan tidak memiliki kemampuan atau kekuatan yang bisa mendatangkan malapetaka bagi orang kampung. Pandangan dan anggapan Pak Itam itu memiliki kesamaan seperti pandangan remaja 
kampung yang telah berpendidikan dan mengenal agama, "hanya saja anak-anak, remaja atau yang sudah sekolah di kota tidak mempercayainya" ("DyS", 2020:3). Kutipan tersebut menunjukkan bahwa pendidikan (sekolah) dan ilmu agama, memiliki peran signifikan bagi individu untuk menerima atau menolak kepercayaan-kepercayaan yang telah lama berkembang yang cenderung mengarah ke takhayul dan mitos.

\section{Hegemoni Kepercayaan}

Hegemoni kepercayaan yang dimaksud dalam cerpen ini adalah segala bentuk kekuasaan satu pihak ke pihak lain berdasarkan kepercayaan. Pihak yang memiliki kuasa adalah Wak Atan dan pihak yang dikuasai adalah Nenek Sari atau dukun. Kekuasaan atau kekuatan yang dimiliki Wak Atan berdasarkan pengetahuan dan kepercayaan . Pengetahuan Wak Atan dan sebagian orang kampung datang berdasarkan pengalaman-pengalaman sebelumnya. Kepercayaan yang dianut Wak Atan mengatakan bahwa keberadaan dukun mampu mendatangkan malapetaka atau mengakibatkan lahan gagal panen. Atas pengetahuan dan kepercayaan ini, mampu menimbulkan tindakan-tindakan yang tidak dibenarkan. Wak Atan ingin membunuh dukun itu. Membunuh tanpa alasan yang dibenarkan secara hukum dan logika tidak dibenarkan. Akan tetapi, tindakan tersebut menurut Wak Atan dibenarkan karena didukung oleh sebagian orang kampung dan keprcayaan yang telah lama dianutnya. Hegemoni kepercayaan itu, memarjinalkan keberadaan manusia yang diduga berperan sebagai dukun, yakni Nenek Sari. Nenek Sari pun secara psikis menerima dengan suka rela dengan status inferior.

\section{Simpulan}

Cerpen "Dukun yang Selamat" karya Joni Hendri menggambarkan kepercayaan masyarakat terhadap keberadaan dukun di sebuah kampung. Tiap-tiap tokoh dalam cerpen itu, memiliki padangan dan kepercayaan yang berbeda. Tokoh Wak Atan memosisikan diri sebagai tokoh yang melawan kehadiran atau keberadaan tokoh Nenek Sari (dukun). Tokoh Wak Atan bahkan mempercayai bahwa keberadaan dukun di kampungnya, bisa mendatangkan bala di antaranya gagal panen. Wak Atan dan sebagian orang kampung mempercayai peristiwa yang bersifat mitos dan takhayul. Tokoh Pak Itam juga mempercayai bahwa Nenek Sari adalah seorang dukun. Pak Itam tidak melawan dukun itu, justru mengasihani dan menyelamatkannya dari ancaman Pak Itam dan orang kampung. 
Tokoh Pak Itam juga tidak mempercayai mitos dan takhayul yang menyebutkan gagalnya panen di sebuah kampung disebabkan dukun Nenek Sari. Tokoh Nenek Sari ayng diindikasikan dukun, dalam cerpen relatif tidak banyak memiliki peran. Nenek Sari sebagai objek utama dari tokoh Wak Atan dan Pak Itam.

Hegemoni dalam cerpen "DyS" ini merujuk pada kekuasaan tokoh Wak Atan terhadap Nenek Sari. Wak Atan memiliki power sehingga cenderung agesif (menyerang) nenek Sari. Konflik antara dua tokoh itu muncul manakala ladang Wak Atan tidak berbuah dan meyakini Nenek Sari sebagai penyebabnya. Kepercayaan itu menjadikan segala bentuk tindakan Wak Atan terhadap dukun itu diakini keberannya. Keprcayaan dalam konteks ini, mampu menghegemoni pihak yang mempecayainya. Tokoh Wak Atan yang telah terhegemoni kepercayaan, tidak lagi mampu berpikir logis dan membuktikan secara ilmiah (empirik) bahwa dukun memiliki peran untuk menggagalkan panen (padi tidak berbuah). Wak Atan lebih mempercayai mitos, kepercayaan, dan cerita lama bahwa pengalaman dirinya membuktikan bahwa penyebab malapetaka di kampungnya dalah dukun. Pengetahuan yang kemudian menjadi keprcayaan Wak Atan bersumber atas pengalaman dirinya.

\section{Daftar Pustaka}

Falah, F. (2018). 'Hegemoni Ideologi dalam Novel Ayat-Ayat Cinta Karya Habiburrahman el Shirazy (Kajian Hegemoni Gramsci)', Nusa: Jurnal Ilmu Bahasa dan Sastra', 13(3), pp. 351-360.

Falah, F. (2019). 'Hegemoni Ideologi dalam Cerpen "Surga untuk Lelaki yang Tertipu" Karya Adam Yudhistira (Kajian Hegemoni Gramsci))', Nusa: Jurnal Ilmu Bahasa dan Sastra', 14(1), pp. 1-10.

Falah, F. (2019). 'Kepercayaan dan Hegemoni dalam Cerpen "Makelar" Karya Sri Lima R.N. (Kajian Hegemoni Gramsci)', Nusa: Jurnal Ilmu Bahasa dan Sastra', 14(2), pp. 136-146.

Hendri, Joni. 2020. "Dukun yang Selamat". Harian Tanjungpinang Pos. Kepulauan Riau. Diakses melalui https://lakonhidup.com/2020/03/08/dukun-yang-selamat/ pada 25 Maret 2020 pukul 13.01 WIB.

Kurniawan, Heru. 2012. Sosiologi Sastra: Teori, Metode, dan Aplikasi. Yogyakarta: Graha Ilmu.

Setyawati, G. et al. (2010) 'Modal Sosial dan Pemilihan Dukun dalam Proses Persalinan : Apakah Relevan? Pendahuluan', 14(1), pp. 11-16. 